\title{
The history of Chesapeake Bay's blue crab (Callinectes sapidus): fisheries and management
}

\author{
Cluney Stagg ${ }^{1}$ and Marguerite Whilden ${ }^{2}$ \\ Fisheries Service, Maryland Department of Natural Resources \\ 580 Taylor Avenue, Tawes B-2 ${ }^{1}, \mathrm{C}-2^{2}$ \\ Annapolis, MD 21401, USA
}

\begin{abstract}
Major blue crab fisheries have existed on the Atlantic coast of the United States for at least 100 years, and on the Gulf of Mexico coast for more than 50 years. From 1990 to 1994, reported landings averaged more than 96 million kg per year, with a reported dockside value of more than \$200 million. Until about 1950, Chesapeake Bay accounted for over $75 \%$ of the total reported U.S. harvest of blue crabs, but less than $50 \%$ over the last two decades. The United States blue crab fishery is made up of hundreds to thousands of small-scale fishermen. The commercial fishery has a hard crab component and a soft crab (recently molted) fishery. There is also a substantial recreational (casual) fishery for blue crabs. Since the 1950s, crab pots have accounted for the largest proportion of reported landings. Other major gears include the trotline, crab scrape and crab dredge. U.S. blue crab fisheries have undergone periods of low abundance. Changes in fishing effort and power, environmental conditions, ecological interactions and market forces have been hypothesized as causative factors. Management measures in the Chesapeake Bay blue crab fisheries have included size and life stage, season, and gear limitations, as well as entry restrictions. An historical perspective should be taken in the interpretation of the recent decline in reported harvests. A 1997 stock assessment concluded that Chesapeake Bay blue crab stocks were fully exploited but in no current danger of recruitment overfishing.
\end{abstract}

Key words: fisheries, management, blue crab, Callinectes sapidus, Chesapeake Bay.

\section{Perspectiva histórica de la pesquería y del manejo del cangrejo azul (Callinectes sapidus) en la Bahía de Chesapeake}

RESUMEN. Importantes pesquerías de jaiba azul han existido en la costa Atlántica de los Estados Unidos por lo menos durante 100 años, y en la costa del Golfo de México por más de 50 años. Desde 1990 a 1994, los desembarques informados promedian más de 96 millones de $\mathrm{kg}$ por año, con un valor playa de más de US\$200 millones. Hasta cerca de 1950, la Bahía de Chesapeake contribuía sobre el 75\% del total de la captura de jaibas azules informada para EE.UU., pero menos del $50 \%$ en las últimas dos décadas. La pesquería de jaiba azul de los Estados Unidos está conformada por cientos a miles de pescadores artesanales. La pesquería comercial tiene una componente de jaibas duras y una pesquería de jaibas blandas recién mudadas. También existe una importante pesquería recreacional (casual) de jaibas azules. Desde los años 50, el uso de trampas para la captura de jaibas han contribuido en mayor proporción a las capturas reportadas. Otros artes utilizados incluyen la "trotline", rastra de jaibas y draga. Las pesquerías de jaiba azul en EE.UU. han tenido períodos de baja abundancia. Cambios en el esfuerzo y poder de pesca, condiciones ambientales, interacciones ecológicas y fuerzas de mercado han sido hipotetizadas como factores causales. Las medidas de manejo de las pesquerías de jaiba azul en la Bahía de Chesapeake han incluido limitaciones de la talla y ciclo de vida, períodos de pesca y limitaciones a los arte de pesca, así como restricciones al ingreso. Debe tomarse una perspectiva histórica en la interpretación de la reciente declinación en las capturas registradas. Una evaluación de stock realizada en 1997 concluye que los stocks de jaiba azul de la Bahía de Chesapeake están completamente explotados pero no en actual peligro de sobrepesca por reclutamiento.

Palabras claves: pesquería, manejo, cangrejo azul, Callinectes sapidus, Bahía de Chesapeake.

\footnotetext{
${ }^{1}$ Present Address: P.O. Box 673, 12 Cold Springs Road, Angwin, CA 94508.
} 


\section{INTRODUCTION}

The intent of this paper is to recount the history of blue crab, Callinectes sapidus, fisheries and management in the Chesapeake Bay region and to briefly examine other United States blue crab fisheries. Information on reported landings and fishing effort is included, as well as an accounting of specific management actions taken over the course of more than a century.

\section{Brief life history}

The blue crab is found from Nova Scotia to Uruguay (Rathbun, 1896; Milliken and Williams, 1984), occurring in rivers, sounds, and near-shore waters of the Atlantic. Blue crabs are fished commercially and recreationally in the United States from southern New England to Florida and along the Gulf coast to Texas.

The blue crab population in Chesapeake Bay is considered to be a single stock, and is distributed throughout the Bay and its tributaries (Rugolo et al., 1997). Males are generally found in areas with lower salinity levels than females and most mating occurs in brackish mid-Bay waters. Mature females move south to the mouth of the Chesapeake Bay in late summer and fall where spawning occurs from May to September of the following season. Larvae are transported out of the bay along the coastal shelf and then back into the bay (McConaugha et al., 1983; Johnson et al., 1984; Johnson, 1985; Johnson and Hess, 1990).

Conventional wisdom has assumed that blue crabs in Chesapeake Bay live to a maximum of three years (Van Engel 1958; Milliken and Williams, 1984). In the course of recent Chesapeake Bay Stock Assessment Committee (CBSAC) research (Rugolo et al., 1997), review of the literature revealed evidence of blue crabs attaining an age of at least five years, based on a North Carolina tagging study (Fischler, 1965). Based on that study and other unpublished tagging data, the CBSAC stock assessment assumed a maximum theoretical age, under virgin stock conditions, of age eight.

Carapace width modal analysis and laboratory rearing studies have led most researchers to assign approximate age classes as follows: Age 0 class- 0 to $<60 \mathrm{~mm}$, Age 1 class-60 to $<120 \mathrm{~mm}$, and Age $2+$ class(es)->120 mm (Rugolo et al., 1997). Definitive growth studies do not exist. Prior to the last few decades of increasing fishing effort, male blue crabs were routinely captured up to $180 \mathrm{~mm}$ carapace width.
Because there are obvious morphological differences between immature and mature female crabs, reproductive maturity in female crabs can be determined by visual inspection. Based on an examination of 6,500 crabs few mature individuals were observed at carapace width less than $100 \mathrm{~mm}$, and essentially no immature individuals were assumed at widths greater than $140 \mathrm{~mm}$ (Rothschild and Ault, 1992).

\section{Overview of the fishery}

Blue crabs were harvested and cultured for local consumption from colonial times (Churchill, 1921). Since crabs were not easily preserved and transported, a wide market could not be established. Ice and faster transport allowed for a broader regional market. The soft crab (or molting crab) first gained attention, as a luxury food, and by 1880 , a directed commercial fishery for blue crabs had begun in the Chesapeake Bay region (Churchill, 1921), which has subsequently spread throughout its range in North America.

The United States blue crab fishery has many components, but in each region, it is a fishery made up of hundreds to thousands of small-scale, sometimes artisanal, fishermen. The commercial fishery is usually separated into a hard crab segment and a peeler and soft crab fishery, the latter component accounting for a small percent of the reported landings. Hard crabs are sold in the "live-trade" market to restaurants and directly to consumers, to processors where crab meat is prepared for resale, and in overseas markets. Soft crabs are sold live or frozen within the United States and in export markets. There is also a substantial recreational (casual) fishery for blue crabs.

Since the 1950s, crab pots (introduced in the 1930s) have accounted for the largest proportion of reported landings. Other major gears include the trotline, crab scrape and crab dredge. The balance of this paper will discuss the evolution of blue crab fisheries in the United States, particularly focusing on Chesapeake Bay crabbing gears, regulations and management.

\section{REPORTED LANDINGS}

Mandatory reporting of commercial landings replaced voluntary reporting in Maryland in 1981, and in Virginia in 1993. Major blue crab fisheries have existed on the Atlantic coast of the United States for at least 100 years, and on the Gulf of Mexico 
coast for more than 50 years. From 1990 to 1994, reported landings averaged more than 96 million $\mathrm{kg}$ per year, with a reported dockside value of more than \$200 million. Until about 1950, Chesapeake Bay accounted for over $75 \%$ of the total reported U.S. harvest of blue crabs. Since that time there has been a slow decline in the region's market share to an average of less than $50 \%$ and to as low as about $35 \%$ over the last two decades.

As reported by the United States National Marine Fisheries Service (NMFS), regions other than the Chesapeake Bay began to develop their blue crabs fisheries around 1945 (Fig. 1). The NMFS has historically defined reporting regions as follows: Middle Atlantic (New York, New Jersey and Delaware), Chesapeake Bay (Maryland and Virginia), South Atlantic (North and South Carolina, Georgia, and Florida) and Gulf of Mexico (Florida, Alabama, Mississippi, Louisiana and Texas). By 1950, the South Atlantic and Gulf of Mexico regions were beginning to bring considerable quantities of blue crab to market. Although of some regional importance, the Middle Atlantic states contribute a relatively small amount to the national total. From 1990 to $1994,6.1 \%, 36.5 \%, 28.2 \%$, and $29.2 \%$ of total U.S. blue crab landings were attributed, respectively, to the Middle Atlantic, Chesapeake Bay, South Atlantic and Gulf of Mexico regions (NMFS, 1995).
The two states of Maryland and Virginia have historically produced and continue to market more blue crabs than any other region.

\section{Chesapeake Bay}

According to the original systematic study of the blue crab, The Life History of the Blue Crab, the species was first marketed in the United States around 1873 when soft shell blue crabs were shipped from Crisfield, Maryland to Philadelphia, Pennsylvania (Churchill, 1921). The hard blue crab fishery originated in 1878 with the opening of a cannery in Virginia, and by 1880 , demand was widespread. Crisfield, Maryland became the hub for soft crab rail shipments to northern cities. Demand grew for both soft and hard crabs in the restaurants of Philadelphia and New York. Chesapeake crab stocks accommodated rapidly increasing harvests to supply an expanding market which grew from 4 million $\mathrm{kg}$ in 1890 to 9 million $\mathrm{kg}$ by 1900 . Available information indicates that reported harvests continued to increase from 1880 to 1915 , perhaps largely due to improved shipping facilities and the use of ice (Fig. 2).

A 1924 report predicted the demise of the blue crab stock and industry because of a $55 \%$ decrease in reported harvests from 1915 to 1920 (Earle, 1925). Thereafter, reported landings recovered somewhat,

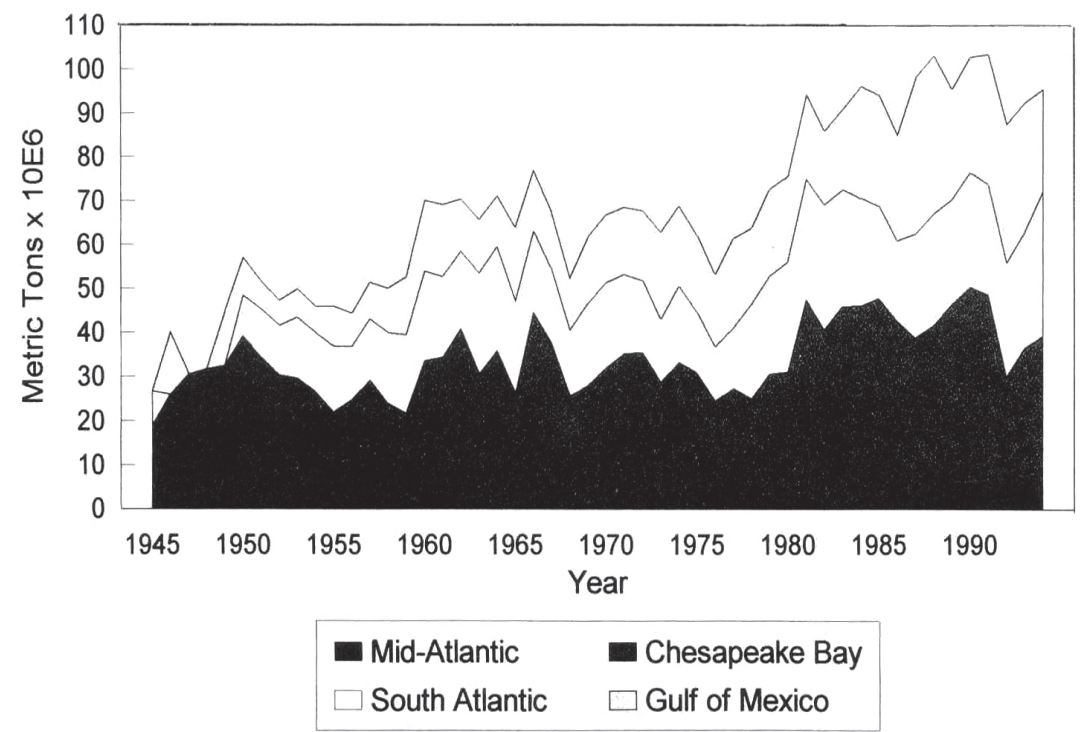

Figure 1. Reported United States commercial blue crab landings by region, 1945 to 1994.

Figura 1. Registro de desembarques comerciales de jaiba azul por región en los Estados Unidos, desde 1945 a 1994. 


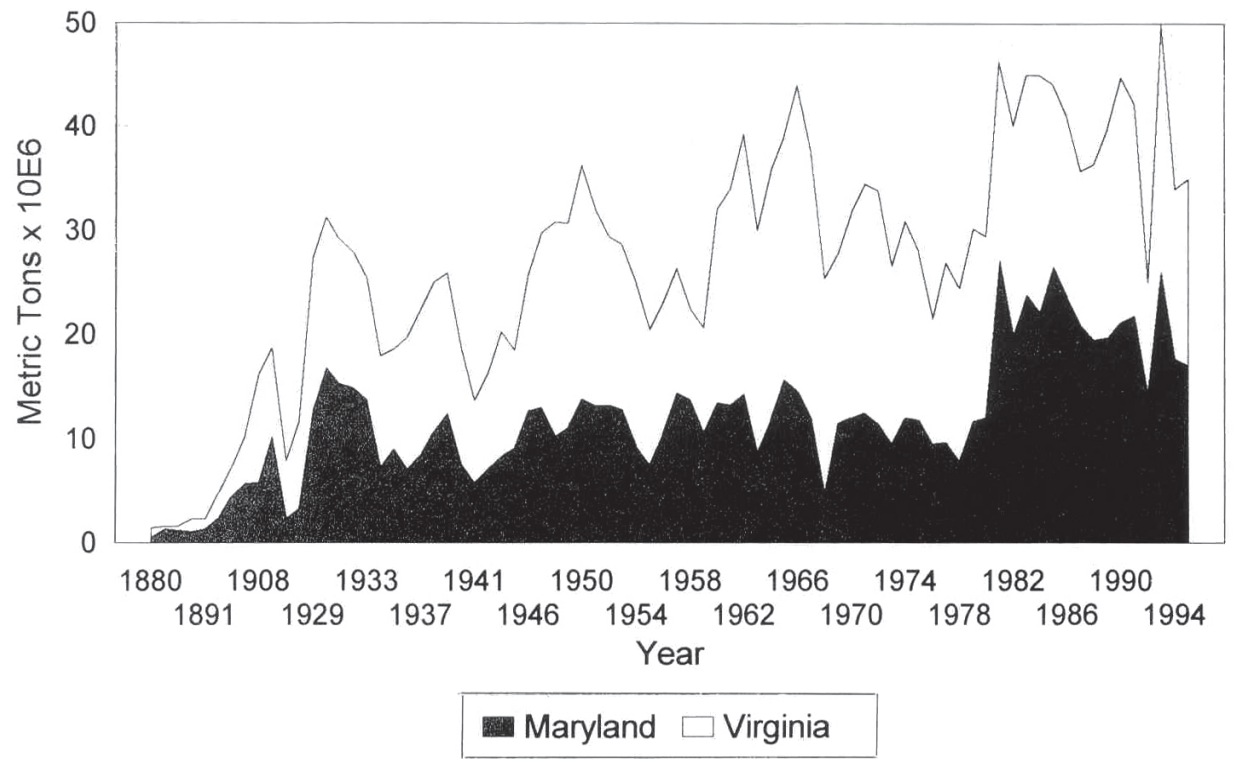

Figure 2. Reported commercial blue crab landings for the Chesapeake Bay region (Maryland and Virginia), 1880 to 1995.

Figura 2. Registro de desembarques comerciales de jaiba azul en la región de la Bahía de Chesapeake (Maryland y Virginia), de 1880 a 1995.

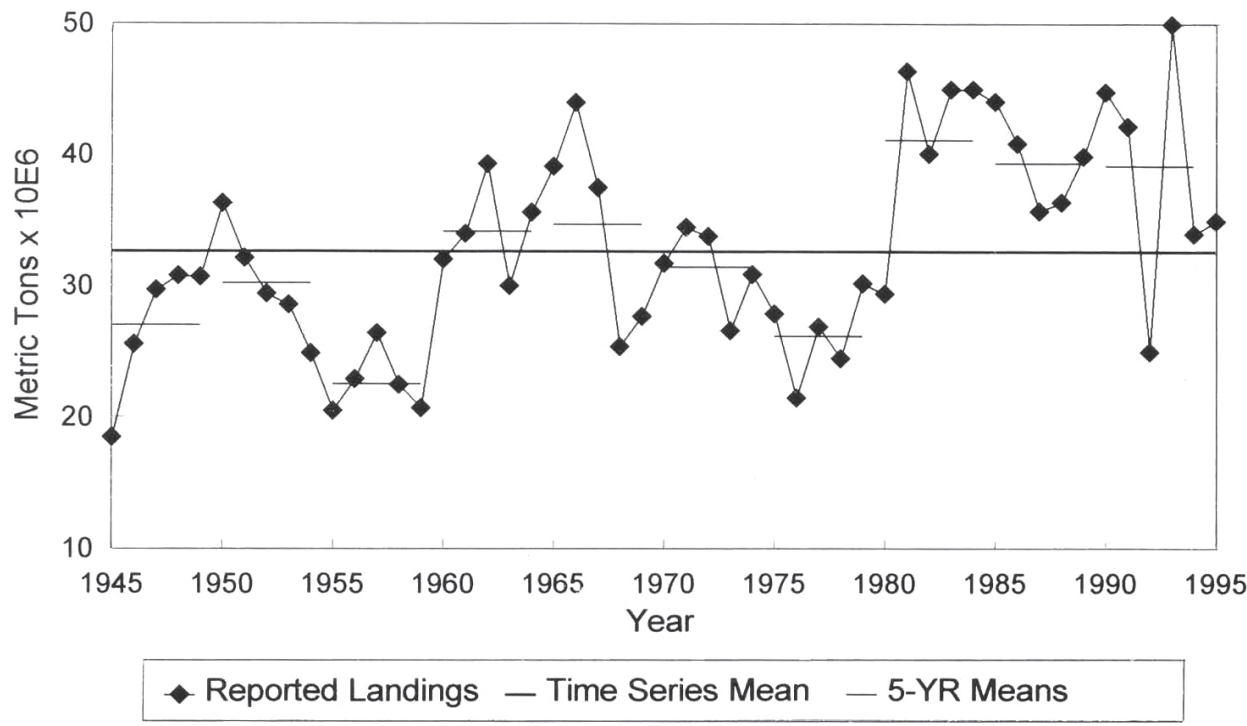

Figure 3. Reported Chesapeake Bay commercial blue crab landings showing long-term and 5-yr means, 1945 to 1995.

Figura 3. Registros de desembarques comerciales de jaiba azul en la región de la Bahía de Chesapeake mostrando medias de largo plazo y de cinco años, de 1945 a 1995. 
there was year-to-year variability, and a new low in reported harvest occurred during the period of World War II (Fig. 2). In 1939, another comprehensive study predicted depletion and collapse of the blue crab resource unless a number of specific management measures were taken (although in the same report, the author noted that the blue crab's high fecundity and short life span enabled it to "survive at great odds") (Truitt, 1939). Thereafter, reported harvests generally increased to record levels from 1945 until this decade, interspersed with intervals of reduced harvests (Figs. 2 and 3).

Historically the blue crab fishery in Chesapeake Bay has undergone periods of low abundance that cannot be ascribed solely to reported changes in fishing effort and power. If reported harvests are any indication of abundance, there were three periods of prolonged, relatively low abundance since 1929 (Figs. 2 and 3), superimposed over a long-term increasing trend. These periods were from 1930 to 1945 , although this is confounded by the effects of reduced fishing during the second world war, from 1951 to 1960 , and from 1968 to 1980 . In each of these periods apparent abundance was below the long-term average from 1945 to 1994 (Fig. 3). Environmental conditions, ecological interactions and market forces have been hypothesized as reasons for these periods of lower harvest (and probably lower stock). Any interpretation of recent declines in reported harvests must consider this historical perspective.

The three highest reported landings in the Chesapeake Bay were in 1981, 1985 and 1990 at roughly 45 million $\mathrm{kg}$. There has been some debate over the 1981 reported landings because at the time Maryland changed from a voluntary census to a mandatory sampling system (Summers et al., 1983a, 1983b). Although, there is evidence to suggest that the apparent increase in abundance was not a reporting artifact (below). A year after one of the worst harvests in Maryland, commercial crab catches increased to 26 million $\mathrm{kg}$ in 1993, 50 million $\mathrm{kg}$ total for Chesapeake Bay the highest since commercial records were kept. For the Chesapeake Bay, reported landings were estimated to be about 40 million $\mathrm{kg}$ in 1995 . These record harvests coincide with the adoption of mandatory reporting in Virginia and the possibility that these record harvests are at least partially an artifact of the new reporting system should not be discounted.

The use of reported landings data alone to as- sess relative abundance is usually biased because it does not account for changes in fishing effort and power. Since 1981 it has been possible to estimate catch per unit effort (CPUE) in the Maryland commercial blue crab pot fishery (Fig. 4). CPUE has closely paralleled Maryland total reported landings since 1981.

Fishery independent sampling, if designed and implemented properly, is more reliable than fishery-dependent data because it employs standardized sampling methods and it is not dependent on individuals who might have an economic interest in not reporting their catch and effort accurately. Two notable fishery independent surveys have been conducted to assess the status of the Chesapeake Bay blue crab stock: the Calvert Cliffs pot sampling study and the bay-wide winter dredge survey.

The Calvert Cliffs study, ongoing since 1968 and uses standardized sampling methods. Commercial crab pots of $25-\mathrm{mm}$ galvanized wire mesh were used to sample crab stocks at three stations in Maryland near Calvert Cliffs from late spring until late fall. The pots were generally fished every other week (Abbe, 1983; Abbe and Stagg, 1996). Catch per pot by size class $(6.35 \mathrm{~mm})$ and sex were recorded, and average annual CPUEs were estimated.

The long-term trend indicates comparable relative abundances from 1968 to 1980 and from 1987 to the present, with a notable and significant increase in relative abundance from 1981 to 1986 (Fig. 4). This pattern is similar to that seen in reported catch data and is evidence that the large increase in reported landings in 1981 is not attributable to reporting changes. Correlation analysis has shown that the time series of CPUE estimated from the Calvert Cliffs data is significantly correlated with reported Maryland commercial catch $(r=0.70, p<0.0001)$, Maryland commercial crab pot CPUE ( $\mathrm{r}=0.881$, $\mathrm{p}<0.0001)$ and total reported Chesapeake Bay catch $(\mathrm{r}=0.686, \mathrm{p}<0.0001)$ (Abbe and Stagg, 1996).

The second fishery-independent sampling program is the blue crab winter dredge survey begun in 1989 (Rothschild and Ault, 1992). The program was based on the fact that blue crabs become inactive when the water temperature falls below $10^{\circ} \mathrm{C}$. During winter is then the best time to sample, when there is little-to-no movement of crabs in or out of the system. Crabs are randomly sampled throughout Chesapeake Bay using a lined dredge (mesh of 12 $\mathrm{cm}$ ) and has been shown to catch crabs as small as 


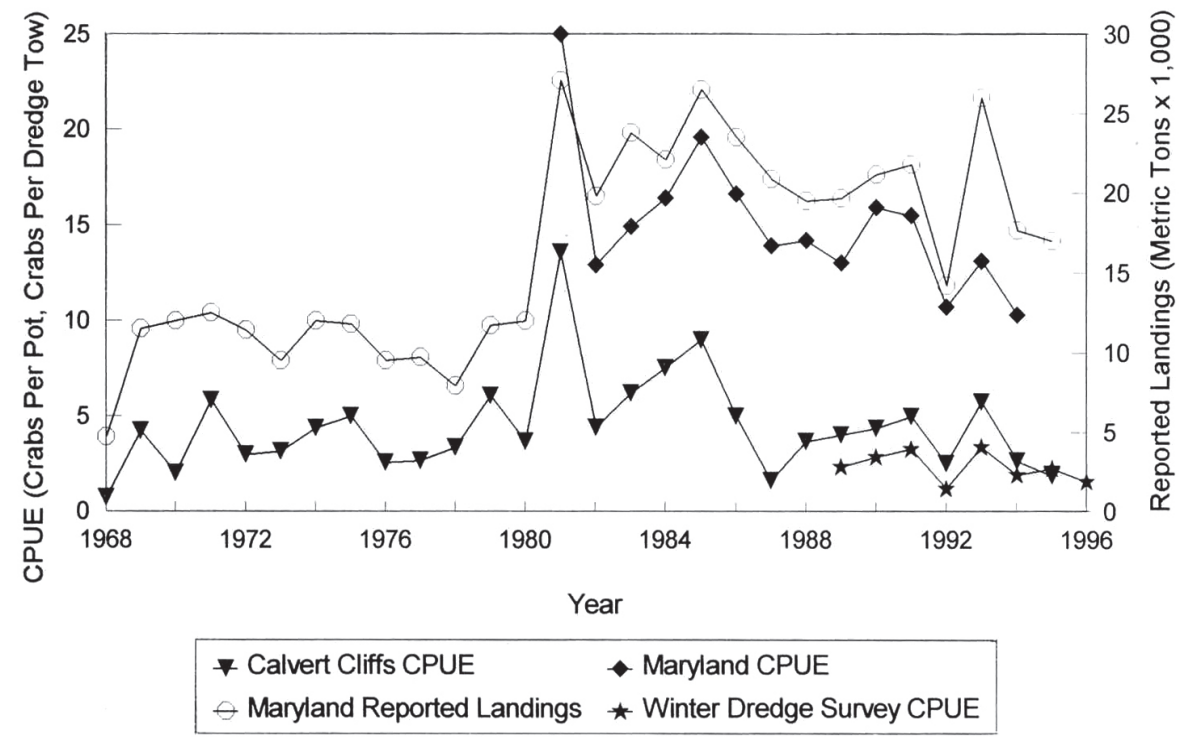

Figure 4. Comparison of trends in Maryland reported blue crab landings (1968 to 1995), Maryland blue crab CPUE (1981-1993), Calvert Cliffs blue crab pot sampling study CPUE (1968 to 1995), and bay-wide blue crab winter dredge survey CPUE (1989 to 1996).

Figura 4. Comparación de tendencias en los desembarques de jaiba azul registrados en Maryland (1968 a 1995), CPUE de la jaiba azul para Maryland (1981-1993), CPUE del estudio de muestreo de Calvert Cliffs para trampas de jaiba azul (1968 a 1995), y CPUE de la exploración de dragado en toda la bahía, en invierno (1989 a 1996).

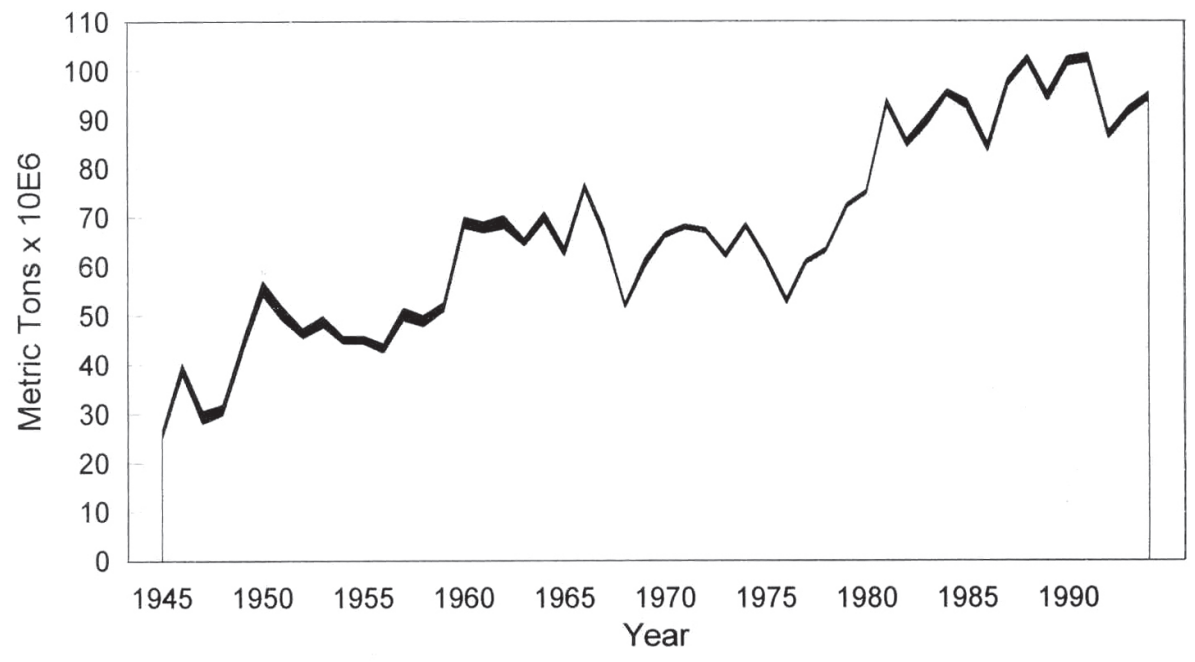

Reported Hard Crab Landings Reported Soft Crab Landings

Figure 5. Reported United States commercial blue crab landings by hard and soft crab market categories, 1945 to 1994.

Figura 5. Desembarques de jaiba azul informados por Estados Unidos para el mercado de las categorías de jaiba dura y blanda, de 1945 a 1994. 
$15 \mathrm{~cm}$ reliably (Rothschild and Ault, 1992). Sex and carapace width are recorded to the nearest $\mathrm{mm}$, nominal age classes are assigned as age $0(0$ to $<60 \mathrm{~mm})$, age $1(60$ to $<120 \mathrm{~mm})$ and age $2+(\geq=120 \mathrm{~mm})$ (Fig. $4)$. Nominal age class 1 has been shown to be a good predictor of (1) Maryland reported harvest and (2) Calvert Cliffs Age 2+ CPUE in the same year as the survey (Rugolo et al., 1997).

\section{Hard and soft crab landings}

United States blue crab markets are usually divided into hard crab landings and peeler and soft crab landings. Hard crabs have hard carapaces and are between molts, whereas peelers are hard crabs showing signs under the existing shell (the emerging new shell) of imminent molting, and soft crabs are crabs that have recently molted, and not yet hardened. Soft crabs are caught in the wild in that state, but more often are produced in an operation that holds peelers in shedding tanks until molting occurs. This adds some stability to the industry.

Hard blue crab landings have historically accounted for more than $90 \%$ of blue crab landings by mass, not numbers (Fig. 5). From 1990 to 1994, U.S. reported blue crab landings averaged 96.2 million $\mathrm{kg}$ of which $98.4 \%$, or 94.7 million $\mathrm{kg}$ were hard crabs. The highest level of soft crab production is in the Chesapeake region, where $2.7 \%$, by weight, of reported landings over the same period were soft crabs.

Soft crabs have always been more valuable on a per unit basis than hard crabs, but not in absolute terms (Fig. 6). From 1990 to 1994, hard crabs averaged $\$ 1.38$ per $\mathrm{kg}$ while soft crabs averaged $\$ 6.08$ per $\mathrm{kg}$, a ratio of 1:4.4. The average combined value of U.S. blue crab landings was \$140.2 million from 1990 to 1994 , of which $93.2 \%$, or $\$ 130.7$ million was derived from hard crab landings. By contrast, Chesapeake Bay landings averaged $\$ 53.1$ million of which $89 \%$, or $\$ 47.3$ million was attributable to hard crab landings.

\section{Recreational and commercial landings}

The magnitude of U.S. recreational or casual landings is largely unknown. Surveys conducted in Maryland in 1983, 1988, and 1990 estimated recreational harvest to be 18.7, 9.7 and 5.2 million $\mathrm{kg}$ (Stagg et al., 1994). These values ranged from 25 to $80 \%$ of the reported Maryland commercial landings in those years, a sizeable component of total removals. The surveys were a combination of access-intercept methods to determine catch rates at strategic points and random-digit dialing telephone surveys to estimate effort (number of trips per household). There is some concern that biases relating to landings by out-of-state crabbers and shoreline property owners were not adequately dealt with in these surveys.

With respect to value, the most recent estimate of recreational harvest was for the 1990 season and was the lowest of the three available Maryland estimates. For the months of May through October, about 2.5 million crabbing trips were estimated to have been made, with an average crabber taking about five trips per season. From the 1991 National Survey of Fishing, Hunting and Wildlife-Associated Recreation (USFWS, 1993), it is estimated that the average saltwater angler spent $\$ 562$ for the season for all expenditures. Given the relatively small investment in equipment for recreational crabbing, an estimate of $\$ 225$ per season covering just expenditures for transportation, rentals, bait, ice and user fees is more reasonable. These estimates suggest that the economic effect of recreational crabbing in Maryland in 1990 was about $\$ 112.5$ million.

\section{Landings by gear}

Blue crabs are captured by a variety of gears, most notably crab pots, trotlines, scrapes, dredges, and otter trawls. Following its patenting in 1938, the crab pot quickly began to replace other gears in the Chesapeake region as the gear of choice. Most crab pots are $0.6 \mathrm{~m}$ squares constructed of $2.9 \mathrm{~cm}$ steel wire, including two or more conical entry ways leading to a baited compartment. Pots are set in up to $18 \mathrm{~m}$ depths, and connected to the surface by a buoyed rope. For the period of available data, 1964 to 1988 , the percentage of the reported harvest landed by crab pots ranged from about 60 to $80 \%$ (Fig. 7). The crab pot is the principal gear in use in all producer states.

Prior to the invention of the crab pot, the crab trotline was the dominant gear and remains important, particularly in Maryland. Trotlines are simply lines (up to $1.6 \mathrm{~km}$ long) with other baited lines attached at regular intervals of 1.8 to $2 \mathrm{~m}$. From 1964 to 1988, the trotline accounted for 5 to $25 \%$ of reported landings.

The crab dredge, a $1.8 \mathrm{~m}$ toothed bar attached to a steel mesh bag, is used exclusively in Virginia's winter fishery and accounted for 5 to 20\% of the reported catch from 1964 to 1988 (Fig. 7). The crab scrape is similar in design to the dredge, 


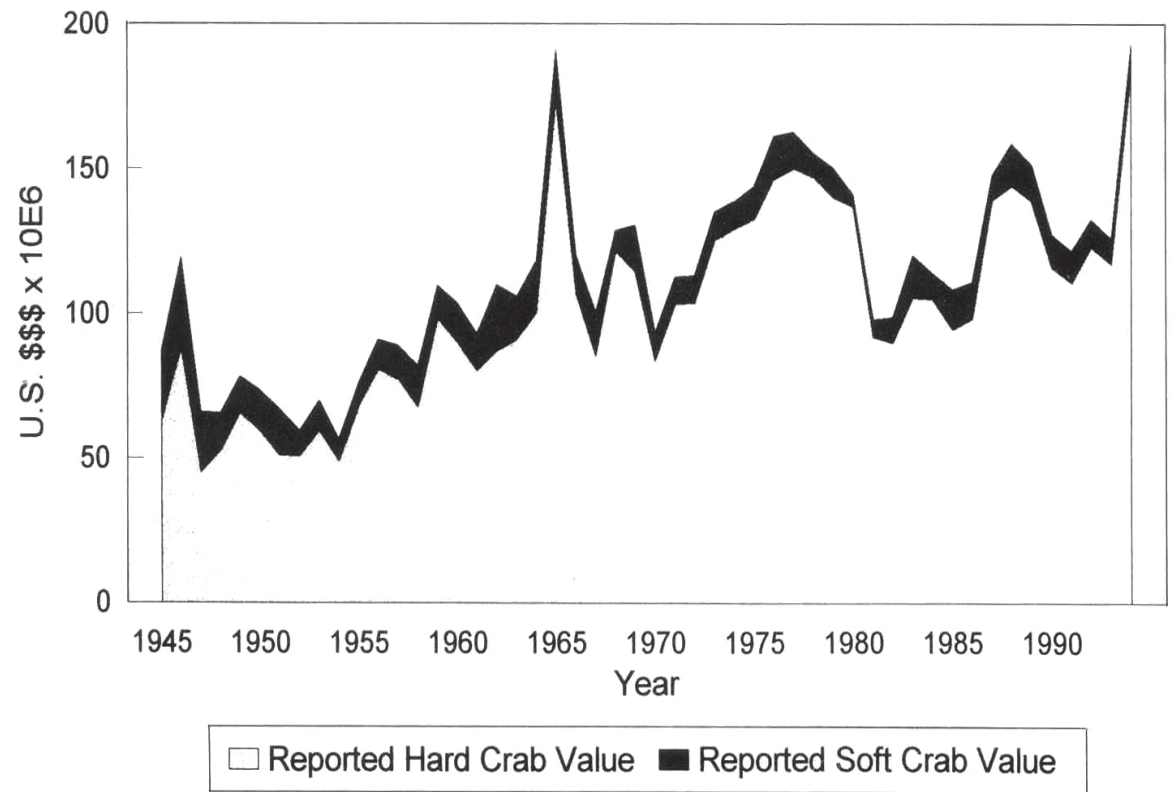

Figure 6. Value of reported United States commercial blue crab landings deflated to 1995 constant dollars, by hard and sot crab market categories, 1945 to 1994.

Figura 6. Valor deflactado a dolar constante de 1995, de los desembarques de jaiba azul informados por Estados Unidos para el mercado de las categorías de jaiba dura y blanda, de 1945 a 1994.

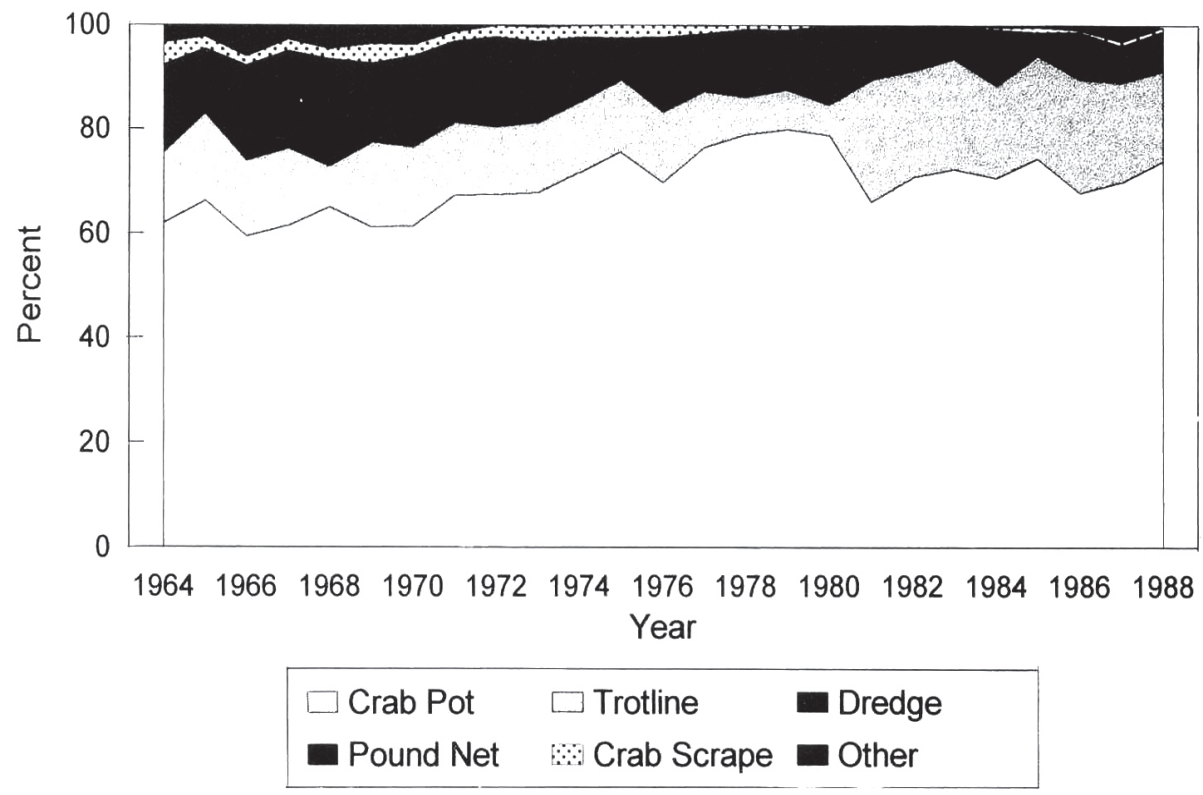

Figure 7. Percent of reported United States commercial blue crab landings landed by major gears, 1964 to FYg8ra 7. Porcentaje de los desembarques comerciales de los Estados Unidos de jaiba azul capturados con los artes más importantes, de 1964 a 1988. 
however it has a burlap bag attached rather than a steel mesh bag. It was developed in 1870, and has historically been most important in the directed peeler-soft crab fishery, although peeler pots (crab pots having a smaller mesh than the standard crab pot) have begun to account for more landings. In the south Atlantic and Gulf of Mexico, crab pots and otter trawls have been particularly important gears.

\section{CHESAPEAKE BAY BLUE CRAB MANAGEMENT}

A brief history of Chesapeake Bay blue crab management actions is presented below. There is practical benefit in comparing the implementation of various regulations with periods of poor harvests. To do this properly, the effects of other activities such as the status of alternative fisheries, weather patterns, national trends in nutrition and diet, and conservation issues in general should be assessed. However, such a comprehensive inquiry is beyond the scope of this review, as is a comparative study of blue crab management among producing states.

Since the first significant decline in blue crab landings in 1924, implementation of management measures have to some extent been responses to real or perceived decreases in crab apparent abundance, although as is the case with most natural resource commodities, blue crab management largely came about for economic reasons. Fisheries management measures include, size and life stage, season, and gear limitations, as well as entry restrictions either through licensing or direct effort control. The history of blue crab management includes all of these.

An accounting of when specific types of regulatory measures were first enacted in the Chesapeake Bay region follows: Licenses were first required for blue crab harvesting in Chesapeake Bay in 1898. The first closed season was initiated in 1906. In 1916, a prohibition on taking egg-bearing females and a $127 \mathrm{~mm}$ size limit for hard crabs was established. By 1941, the types of gear that could be used to harvest crabs was restricted (dredges were eliminated as a legal gear in Maryland) and a crab sanctuary (area closure) was adopted. In 1943, the amount of gear that could be deployed on one license was restricted, specifically number of crab pots. In 1988 the Maryland legislature enacted a delayed entry program in an attempt to cap effort.

\section{Early blue crab management, Pre-1925}

Licenses were first required for blue crab harvesting in Chesapeake Bay in Virginia in 1898 more for revenue generation than for fishery management. According to archive files, some local governments in Maryland issued their own crabbing licenses as early as 1903. Crabbing in Maryland was not licensed or taxed by the state until 1916; licenses were issued on a county basis as watermen were required to harvest within their county of license (some counties offered reciprocity). Non-residents were prohibited from obtaining a crabbing license in Maryland until 1983 when both Maryland and Virginia as a result of litigation recognized reciprocal licensing.

New harvest methods continued to be developed. Watermen dredging oysters found "hibernating" crabs in their rigs and soon began dredging for crabs during the winter months. In 1906, Maryland established a crabbing season from May through October, thus, eliminating a winter harvest. Virginia continued to allow winter dredging, which in 1920 accounted for $13 \%$ of the total Chesapeake harvest and remains an important harvest to this day.

After the establishment of a season and a license requirement, size and life stage limits were the next management measures considered in the Chesapeake region. In 1916, Maryland adopted a $127 \mathrm{~mm}$ hard crab minimum size in Somerset County, and Virginia banned the taking of sponge crabs between June 15 and August 31 and enacted a season for winter dredging.

The following year, the Maryland size limit was extended statewide and a prohibition on the possession of sponge crabs and peelers was implemented. Based on reports published in the 1940s, enforcement of these regulations was sporadic at best. For example, a 1939 investigation of the soft crab (peeler) industry revealed that mortality was as high as $80 \%$ (possibly because watermen continued to take peelers which were not ready to shed within a two day period) (Truitt, 1939).

\section{Blue crab management, 1925 to 1981}

An important survey of the Chesapeake blue crab was initiated in August of 1924 by the U.S. Bureau of Fisheries. Much of what we know of the early crab fishery was compiled in the report, The Survey of the Condition of the Crab Fisheries of the Chesapeake Bay, which was published in December 1925. The Survey stated in its purpose that the blue crab 
fishery was "now faced with destruction." The 1924 Survey listed in its synopsis that: the 1924 crab harvest was half of the 23,000 tons taken from the Chesapeake in 1915; abundance had decreased $75 \%$ since $1907 ; 75 \%$ of the adult stock was removed by the commercial catch; 30 to $50 \%$ of peeler crabs were wasted because they were taken too soon, among other things.

There has been a tendency when landings have fallen in the past for political involvement in the management process to increase, and for political involvement to decrease or disappear when landings are stable. There is no better example of this than the "crab crisis" of 1924. The perceived crisis led to a meeting in September of 1924, between the Governors of Maryland and Virginia. The State of Maryland proposed four measures to be adopted by both States: (1) Virginia should ban the taking of sponge crabs during the entire year, instead of June 15 to August 31 (peak spawning period) as was in place at the time; (2) Virginia should shorten the dredging season from 6 months to 3 months (to reduce fishing on dormant overwintering females); (3) Maryland and Virginia should increase minimum size limits to $152 \mathrm{~mm}$ for hard crabs and $90 \mathrm{~mm}$ for soft crabs; and (4) both States should ban the taking of green crabs (under-sized crabs showing no signs of molting). What is notable is none of these proposed actions were put into place.

By 1929, Chesapeake harvests exceeded 27,000 tons, the record harvest up to that point, and little more was adopted to further protect blue crab populations in the ensuing decade. Fishing techniques and participants remained reasonably constant during the 1930s. There were approximately 2,400 Maryland crabbers in 1929 and nearly the same in 1939.

A major turning point in the history of blue crab fisheries and management came with the invention in of the crab pot and by 1940 was in widespread use. When introduced, the crab pot was less labor intensive than other methods, permitted rapid expansion in effort because it became relatively inexpensive to enter the fishery. The same year the crab pot was introduced produced a poor harvest and the crab pot was offered as an explanation. The Maryland legislature excluded the crab pot in a list of legal gears during the 1941 legislative session. The crab pot was reinstated as a legal gear in Maryland in 1943, permitted in the Chesapeake Bay proper and the Potomac River. Crabbers were ini- tially limited to 35 pots, but over the course of several years the limit on crab pots has increased.

In 1941, in response to the concern over the taking of sponge crabs, Virginia set aside a sanctuary for crabs near the mouth of the Chesapeake Bay. When the Department of Chesapeake Bay Affairs was created in Maryland in 1964, a more compete catch reporting system was established (e.g. landings by gear type). By this time, the recreational crabber was increasing in numbers, and judging from the sequence of regulations enacted from 1964 to 1968 , the recreational crabber was a segment of the fishery which had not been an issue until the 1960s. Around this time, the crab pot was designated a commercial gear and not permitted to be used by the recreational crabber.

\section{Blue crab management, 1981 to present}

A monthly sampling survey was initiated in Maryland beginning in 1981, the same year in which the largest catch of record (27,000 tons) was landed. Landings were so good during the 1980s that several of Maryland's crab management measures were rolled back to what they were in the early days of crabbing in the $1880 \mathrm{~s}$.

By 1985, the Department of Natural Resources (MDNR) had issued over 18,000 crabbing licenses, half of which were "non-commercial". In an effort to moderate the expansion of the state's commercial fisheries, Maryland adopted a "delayed entry" licensing program for commercial licenses in 1988, implemented in 1989. Applicants would pay the licensing fee at the time of application and wait two years to receive the fishing permit. Motivated by the producers, who were working longer for fewer crabs, this had less to do with conservation then individual economics. The number of commercial crabbing licenses remained at about 6,000 . The number of "non-commercial" licenses increased rapidly from around 7,000 in 1990 to over 12,000 in 1992.

Between 1992 and 1994, Virginia enacted a number of new laws and regulation pertaining to blue crabs: a commercial license (\$150) was required, two year delayed entry, limited entry in the dredge fishery, the dredge catch limit was lowered from 25 barrels to 20 barrels per day, a $59 \mathrm{~mm}$ cull ring in hard crab pots was required, peeler pot fishermen and soft crab shedders were licensed, mandatory reporting was enacted, a recreational crab licence (\$29) was required as well as a five-pot restriction for recreational crabbers. 
An advisory panel was convened in 1992 to guide MDNR in implementing more protective management of the crab fishery. Consensus was to cap fishing effort at then current levels. The Governor's Crab Action Plan was introduced in the Summer of 1993 with a focus on stabilizing fishing effort and addressing the recreational crabbing issue. The 1993 crab harvest exceeded recent records making it difficult to adopt restrictive measures in the midst of what appeared to be a natural recovery and abundance. Nevertheless, legislation necessary to implement the Governor's plan was introduced to the 1994 General Assembly and regulations were proposed by the Department of Natural Resources.

By 1995, a growing atmosphere of concern that crab stocks were in danger characterized blue crab management in 1995. MDNR organized another blue crab advisory committee and prepared a summary of all blue crab data to date and a blue crab stock assessment was begun by the Chesapeake Bay Stock assessment Committee (CBSAC). Landings for 1995 were slightly below the 10 year average.

In an emergency measure the Governor's office announced that a reduction in the harvest of spawning stock was necessary to stabilize the commercial crab industry. The State set a target of reducing the female catch by $20 \%$. Beginning September 1995, the Chesapeake Bay tributaries were closed to commercial crabbing on Sundays; the main stem of the Chesapeake Bay in Maryland was closed to commercial crabbing on Mondays; commercial hours were reduced to eight hours a day; recreational crabbing was restricted to Fridays, Saturdays, and Sundays; and the crabbing season was closed November 18, 1995.

A blue crab stock assessment was begun in 1995 by the NMFS CBSAC. The stock assessment comprised a review, synthesis and analysis of all available, relevant data on blue crab biology and fisheries (Rugolo et al., 1997). Conclusions of the completed assessment include the following: (1) the Chesapeake Bay blue crab stock "appears stable over the long term while the juvenile population has been increasing over the last decade despite a dramatic increase in commercial fishing effort", (2) despite this increase in effort fishing mortality has remained relatively constant over the long term ("as a result of gear saturation and/or gear competition"), and (3) there are indications of "severe" overcapitalization in the fishery.
The stock assessment did not directly address the question of the effectiveness of the regulatory measures outlined above. Market forces and reaction to perceived crises have historically played a major role in the specification of crabbing regulations. Natural fluctuations in blue crab stocks driven by environmental variables (Tang, 1985), as well as the effects of human intervention, account for the historic pattern of widely-varying blue crab abundance observed in the Chesapeake Bay region.

\section{REFERENCES}

Abbe, G.R. 1983. A study of blue crab populations in Chesapeake Bay in the vicinity of the Calvert Cliffs Nuclear Power Plant, 1968-1981. J. Shellfish Res., 3: 183-193.

Abbe, G.R. and C. Stagg. 1996. Trends in blue crab (Callinectes sapidus Rathbun) catches near Calvert Cliffs, Maryland from 1968 to 1995 and their relationship to the Maryland commercial fishery. J. Shellfish Res., 15: 751758.

Churchill, E.P. Jr. 1921. Life history of the blue crab. Bulletin U.S. Bureau of Fisheries, 36:95128.

Earle, S. 1925. Maryland's efforts to save the blue crab of Chesapeake Bay. Conservation Bulletin $\mathrm{N}^{\mathrm{o}} 1$, State of Maryland.

Fischler, K.J. 1965. The use of catch-effort, catchsampling, and tagging data to estimate a population of blue crabs. Trans. Am. Fish. Soc., 91: 275-278.

Johnson, D.F and K.W. Hess. 1990. Numerical simulations of blue crab larval dispersal and recruitment. Bull. Mar. Sci., 46: 195-213.

Johnson, D.R. 1985. Wind-forced dispersion of blue crab larvae in the Middle Atlantic Bight. Cont. Shelf Res., 4: 733-745.

Johnson, D.R., B.S. Hester and J.R. McConaugha. 1984. Studies of a wind mechanism influencing the recruitment of blue crabs in the Middle Atlantic Bight. Cont. Shelf Res., 3: 425-437.

McConaugha, J.R., D.F. Johnson, A.J. Provenzano and R.C. Maris. 1983. Seasonal distribution of larvae of Callinectes sapidus (Crustacea: Decapoda) in the waters adjacent to Chesapeake Bay. J. Crust. Biol., 3: 582-591. 
Milliken, M.R. and A.B. Williams. 1984. Synopsis of biological data on the blue crab, Callinectes sapidus Rathbun. U.S. Department of Commerce, NOAA Technical Report NMFS 1.

National Marine Fisheries Service (NMFS). Annual Volumes 1945-95, Fishery Statistics of the United States. U.S. Dept. Of Commerce.

Rathbun, M.J. 1896. The genus Callinectes. Proceedings of the U.S. National Museum, 18(1070): 349-375.

Rothschild, B.J. y J.S. Ault. 1992. Assessment of the Chesapeake Bay blue crab stock. Ref. No. UMCEES [CBL] 92-082. Final report for NO/ NMFS Grant NA16FU0529-01.

Rugolo, L., A. Lange, K. Knotts, C. Stagg, R. O'Reilly, M. Terceiro, V. Crecco, and D. Vaughan. 1997. Chesapeake Bay blue crab stock assessment. National Oceanic and Atmospheric Administration, National Marine Fisheries Service, Chesapeake Bay Stock Assessment Committee, Annapolis, Maryland.

Stagg, C, M. Holloway, L. Rugolo, K. Knotts, L. Kline and D. Logan. 1994. Evaluation of the 1990 recreational, charter boat, and commercial striped bass fishing surveys, and design of a recreational blue crab survey. Maryland Dept. Of Natural Resources.

Recibido el 03 de diciembre de 1996. Aceptado el 23 de mayo de 1997.
Summers, J.K., H.W. Hoffman, and W.A. Richkus. 1983a. Randomized sample surveys to estimate annual blue crab harvests by a multi-gear fishery in the Maryland waters of Chesapeake Bay. North Am. J. Fish. Mngt., 3: 9-20.

Summers, J.K., W.A. Richkus., H.W. Hoffman, C. Bonzek, H.H. King and M. Burch. 1983b. Application of random sample surveys to estimate the commercial blue crab harvest in Maryland. North Am. J. Fish. Mngt., 3: 21-25.

Tang, Q. 1985. Modification of the Ricker stock recruitment model to account for environmentally induced variation on recruitment with particular reference to the blue crab fishery in Chesapeake Bay. Fish. Res., 3: 13-21.

Truitt, R.V. 1939. The blue crab. Pages 10-38 In: Our Water Resources and Their Conservation. University of Maryland, Chesapeake Biological Laboratory Contribution Number 27.

United States Fish and Wildlife Service (USFWS). 1993. National survey of fishing, Hunting, and Wildlife Associated Recreation. U.S. Dept. of Interior.

U.S. Bureau of Fisheries. 1925. The survey of the condition of the crab fisheries of the Chesapeake Bay. U.S. Bureau of Fisheries

Van Engel, W. 1958. The blue crab and its fishery in Chesapeake Bay. Part 1. Reproduction, early development, growth and migration. Commercial Fisheries Review, 24(9): 1-10. 